\title{
Efficacy of treatments with toltrazuril $7.5 \%$ and lasalocid sodium in sheep naturally infected with Eimeria spp.
}

\author{
Eficácia de tratamentos com toltrazuril 7,5\% e lasalocida sódica em ovinos \\ naturalmente infectados com Eimeria spp.
}

\author{
Fernando de Souza Rodrigues ${ }^{1 *}$; Luiz Eduardo Roland Tavares ${ }^{2}$; Fernando Paiva ${ }^{2}$ \\ ${ }^{1}$ Laboratório de Doenças Parasitárias, Departamento de Medicina Veterinária Preventiva, Universidade Federal de Santa Maria - \\ UFSM, Santa Maria, RS, Brasil \\ ${ }^{2}$ Laboratório de Parasitologia Animal, Centro de Ciências Biológicas e da Saúde, Universidade Federal de Mato Grosso do Sul - \\ UFMS, Campo Grande, MS, Brasil
}

Received January 20, 2016

Accepted May 12, 2016

\begin{abstract}
The objective of this study was to evaluate the efficacy of an experimental formulation of toltrazuril $7.5 \%+$ Trimix $^{\mathrm{Tm}}$ on a naturally acquired infection of Eimeria spp. in suckling lambs kept on pasture and, in another trial, evaluate the comparative efficacy between lasalocid and toltrazuril $7.5 \%+\operatorname{Trimix}^{\mathrm{TM}}$ in newly weaned sheep under feedlot conditions that had been naturally infected with Eimeria spp. In the first experiment, 30 suckling lambs were divided into two groups: A - treated with toltrazuril $7.5 \%+$ Trimix $^{\mathrm{TM}}$ and B- control. In experiment 2, 30 weaned sheep were divided into three groups: I - treated with toltrazuril $7.5 \%+$ Trimix $^{\text {TM }}$, II - treated with lasalocid and III - control. Treatment group A showed an efficacy of $90,99.4$ and $87.3 \%$ on days 5, 10 and 20, respectively. Treatment group I had an efficacy of 98.2, 92.6 and $94.5 \%$, while group II had an efficacy of $72.7,81.6$ and $95.9 \%$ on days 7,21 and 42, respectively. Eight Eimeria species were identified; E. ovinoidalis was the most common. Treatment with the toltrazuril $7.5 \%+$ Trimix $^{{ }^{\mathrm{m}}}$ formulation was effective against Eimeria spp. in suckling lambs in field conditions and lambs weaned in under feedlot conditions.
\end{abstract}

Keywords: Coccidiosis, Eimeria ovinoidalis, Eimeriosis, diarrhea, toltrazuril, lasalocid.

\section{Resumo}

O objetivo deste estudo foi avaliar a eficácia de uma formulação experimental de toltrazuril 7,5\% + Trimix ${ }^{\mathrm{Tm}}$ em cordeiros mantidos em pastagem com infecção naturalmente adquirida por Eimeria spp. e, em outro teste, a eficácia comparativa entre lasalocida sódica e toltrazuril 7,5\% + Trimix $^{\mathrm{Tm}} \mathrm{em}$ ovinos recém-desmamados, naturalmente infectados com Eimeria spp. em condiçôes de confinamento. No primeiro experimento, 30 cordeiros lactantes foram divididos em dois grupos: A - tratados com toltrazuril 7,5\% + Trimix ${ }^{\mathrm{TM}}$; e B - controle. No experimento 2, 30 ovinos desmamados foram divididos em três grupos: I - tratados com toltrazuril 7,5\% + Trimix ${ }^{\text {Tm}}$; II - tratados com lasalocida sódica; e III - controle. O grupo A (tratado) obteve uma eficácia de 90, 99,4 e 87,3\% nos dias 5, 10 e 20, respectivamente. O grupo I teve eficácia de 98,2, 92,6 e 94,5\%, enquanto o grupo II teve uma eficácia de 72,7, 81,6 e 95,9\% nos dias 7, 21 e 42, respectivamente. Foram identificadas oito espécies de Eimeria, sendo E. ovinoidalis a mais comum. O tratamento com a formulação de toltrazuril 7,5\% + Trimix ${ }^{\mathrm{Tm}}$ foi eficaz contra Eimeria spp. em cordeiros em lactação em condiçóes de campo e em ovinos desmamados em confinamento.

Palavras-chave: Coccidiose, Eimeria ovinoidalis, Eimeriose, diarreia, toltrazuril, lasalocida.

Corresponding author: Fernando de Souza Rodrigues. Programa de 


\section{Introduction}

Eimeria spp. infections in sheep affect animals of all ages and are most common in young animals that have been weaned and those kept in an intensive system. Subclinical coccidiosis is more common, which leads to decreased body weight gain and reduced growth (CHARTIER \& PARAUD, 2012; DIAFERIA et al., 2013). In sheep, 11 species of Eimeria have been described, and E. ovinoidalis and E. crandallis have been considered as the most pathogenic (CHARTIER \& PARAUD, 2012).

Hygiene measures help to reduce infection, but under certain conditions they are difficult to apply; thus, the use of anticoccidial drugs can help control infection. However, the relationship between coccidia and gastrointestinal nematodes must be considered because negative (KANYARI, 1988; AGYEI, 2003; AGYEI et al., 2004) and positive correlations have been described between these parasites (KANYARI, 1993). Thus, it is important to use a protocol of treatments for both kind of parasites and it can be accomplished in a practical way and viable.

Thus, the objectives of this study were: a) to evaluate the efficacy of an experimental formulation of toltrazuril $7.5 \%$ mixed in Trimix $^{\mathrm{TM}}$ (Merial ${ }^{\circledR}$ - ivermectin, levamisole, and albendazole) to treat suckling lambs raised on pasture that was exposed to a naturally acquired infection by Eimeria spp. and b) to evaluate the comparative efficacy of a commercial formulation of lasalocid (Taurotec $^{\circledR}$, Alpharma) with toltrazuril 7.5\% dissolved in Trimix ${ }^{\circledR}$ in newly weaned sheep maintained in feedlot conditions that had been naturally infected with Eimeria spp.

\section{Materials and Methods}

\section{Study site}

The study was conducted in September 2013 and October 2013 on a commercial sheep farm (20 67'35.07'S and 54²7'92.01'W), located in the municipality of Campo Grande, state of Mato Grosso do Sul, Brazil.

\section{Tested formulations}

An experimental toltrazuril formulation containing 7.5\% w/v (99\% PA, Xian Wango Biopharm Co., Ltd. - China) was dissolved in commercial formulation of ivermectin, levamisole, and albendazole (Trimix ${ }^{\mathrm{TM}}$, Merial $^{\circledR}$, São Paulo - Brazil). The Trimix ${ }^{\mathrm{TM}}$ was selected according a previous efficacy test on the experimental farm. The dosage for treatment with the test formulation was $0.26 \mathrm{ml} / \mathrm{kg} / \mathrm{BW}$, which corresponds to $20 \mathrm{mg} / \mathrm{kg}$ of toltrazuril, $0.2 \mathrm{mg} / \mathrm{Kg}$ of ivermectina, $7.5 \mathrm{mg} / \mathrm{Kg}$ of levamisole and $5 \mathrm{mg} / \mathrm{kg}$ of albendazol. The solution was maintained in an amber vial until the moment of administration to animals. The commercial formulation of lasalocid 15\% (Taurotec ${ }^{\mathrm{TM}}$, Zoetis Brazil, São Paulo - Brazil) was added in the feed of the test group at corresponding dose of $1 \mathrm{mg} / \mathrm{kg} / \mathrm{BW}$. The experimental flock were not submitted to treatment with anticoccidial drugs prior to tests.

\section{Experiment - 1}

Thirty suckling lambs of 3-month-old male and female Mato Grosso do Sul Native with a mean body weight of $15.27( \pm 2.71)$ were individually identified and maintained with their dams on grazing on Brachiaria brizantha cv. Piatá. These lambs had free access to creep feeding system during the day.

On day -1, fecal samples were collected directly from the rectum, and examined for oocysts per gram of feces (OPG) using the modified McMaster technique (GORDON \& WHITLOCK, 1939). According to the results of OPG counts, the lambs were separated equally into two groups homogenous as follows: Group A - treated with one dose of the experimental formulation toltrazuril $7.5 \%+$ Trimix $^{\mathrm{TM}}$ and Group B - control group treated only with Trimix $^{\text {тм }}$. On day zero (D0), animals were treated and fecal samples from individual animals were collected on days $0,5,10$, and 20 post-treatment. The treated lambs and controls were kept in the same pasture with their dams.

\section{Experiment - 2}

Forty weaned Mato Grosso do Sul Native sheep with 5-month-old male and female were used; on day -1 (D-1) they were identified individually, body weight was measured and fecal samples were collected and stored in isothermal boxes for transport to the laboratory and maintained at $10{ }^{\circ} \mathrm{C}$ until processing.

Of these, 30 animals were selected with equivalent $\mathrm{OPG}$ and body weight $(19.27 \pm 5.2 \mathrm{~kg})$. These animals were separated into three homogenous groups: Group I (GI) - treated with one dose of the test solution of toltrazuril $7.5 \%+$ Trimix $^{\mathrm{TM}}$, Group II (GII) - treated with a commercial formulation of lasalocid (Taurotec ${ }^{\mathrm{TM}}$ ) plus one dose of Trimix ${ }^{\mathrm{TM}}$ and Group III (GIII) - control group treated with only Trimix ${ }^{\mathrm{TM}}$.

The animals were grazing on $B$. brizantha $\mathrm{cv}$. Piatá before the experiment, and during the experimental period were maintained in a feedlot condition where the feed consisted of the concentrate $17 \%$ protein, corn silage, and water provided in troughs.

On day zero (D0), the GI was treated with toltrazuril plus Trimix $^{\mathrm{TM}}$. GII began daily treatment with the addition of lasalocid in the concentrate throughout the experimental period, where the amount was adjusted according to changes in weight gain and treated with only one dose of Trimix ${ }^{\mathrm{TM}}$ on D0 while GIII no received treatment with an anticoccidial and treated with Trimix $^{\mathrm{TM}}$ on D0

The animals of GI and GIII were weighed on day D-1 and D42 to evaluate weight gain and the animals of the GII group were weighed regularly every 14 days to adjust the amount of lasalocid added to the concentrate. Individual fecal samples of animals were collected on D7, D21, and D42 post-treatment, to determine the OPG of feces for each animal.

\section{Laboratory procedure}

Fecal samples were counting for oocysts using the modified McMaster technique (GORDON \& WHITLOCK, 1939) with a sensitivity of 50 oocysts per gram of faeces. 
To identify the species of Eimeria in fecal samples positive for oocysts, according to the sampling date and experimental group, the sample was homogenized, dissolved in water, and sieved through $60 \mu \mathrm{m}$ mesh steel. Several washes were performed in sedimentation glasses until the supernatant became transparent according to the technique of Hoffman et al. (1934). After two to three steps, when the supernatant was clear and the sample had sediment, the amount of liquid was reduced and potassium dichromate solution at $2.0 \%(\mathrm{w} / \mathrm{v}$ ) in a 1: 1 volume was added. The suspension was kept in erlenmeyer maintained at room temperature under constant agitation in platform shaker for 10 days.

After this period, a sample from each preparation was processed by the flotation technique in a modified concentrated sugar solution (CFA) (UENO \& GONÇALVES, 1998) to recover coccidian and identify the species under microscopy. The following morphometric characteristics were measured: the length and width of oocysts and sporocysts and the wall thickness of oocysts. The morphological characteristics considered for identification were shape, color, and the presence or absence of a micropyle (CHARTIER \& PARAUD, 2012). The oocysts with characteristics of $E$. crandallis and/or E. weybridgensis were considered as a group because of the difficulty for reliable differentiation between these species (O'CALLAGHAN et al., 1987).

\section{Statistical analysis}

The effectiveness of the treatments was evaluated by calculating the reduction of oocyst count using analysis for two samples (paired) in a program for fecal egg count modeling (http://www. math.uzh.ch/as/?calc) following the methodology proposed by Torgerson et al. (2014). The OPG count data were transformed into $\log (x+10)$ and comparisons between the mean oocyst counts in the same period between the groups; OPG comparisons in the same group at different times and the weight of the animals at the beginning and end of the experiment were analyzed by analysis of variance (ANOVA) and post-hoc analysis using the Tukey test, considered $\mathrm{p}<0.05$ significant. All analyses were performed using the Bioestat 5.0 program (Bélem, PA - Brazil) (AYRES et al., 2007).

\section{Results}

In experiment 1 , group A (treatment with the experimental formulation with toltrazuril $7.5 \%+\operatorname{Trimix}^{\mathrm{TM}}$ ) showed an efficacy of 90.0, 99.4 and $87.3 \%$ on days 5, 10 and 20, respectively. Considering the treatment of group (A) compared to the control group (B), a significant difference $(p<0.05)$ in OPG at, D5, D10 and D20 was found between the different days post treatment. The mean OPG values of groups A and B are shown in Table 1. No eggs of helminth were found in McMaster technique after treatment with Trimix ${ }^{\mathrm{TM}}$.

In experiment 2, group I (treatment with solution toltrazuril $7.5 \%+$ Trimix $^{\mathrm{TM}}$ ) showed an efficacy of $98.2,92.6$ and $94.5 \%$, while group II showed an efficacy of $72.7,81.6$ and $95.9 \%$ at D7, D21 and D42, respectively. When comparing the OPG, a significant difference $(p<0.05)$ between the animals of GI and the other treatments (GII and GIII) on day 7 was found. For D21 and D42, no significant differences ( $>$ > 0.05) were found. In GI, a significant difference $(p<0.05)$ in OPG at D0 (pre-treatment) with OPG after treatment (D7, D21 and D42) was found, as well as a significant difference between D7 and D21. GII, which was treated with the formulation containing lasalocid, had significant differences $(\mathrm{p}<0.05)$ between OPG at D7 and D42 and those of the pre-treatment (D0) with days post treatment (D7, D21 and D42). In the control group (GIII), there were significant differences $(\mathrm{p}<0.05)$ between D0 and $\mathrm{D} 42$. The average results for OPG counts during the experiment are shown in Table 2. After treatment with Trimix $^{\text {тм }}$, all animals showed negative results for helminth egg counts in their feces. The average weight gain of sheep was $5.17,7.3$ and $6.91 \mathrm{~kg}$ for GI, GII and GIII, respectively. However, the average weight gain as analyzed by ANOVA did not result in any significant difference between treatment groups.

Eight Eimeria species were identified in both experiments, the most common species being: E. ovinoidalis, E. crandallis/E. weybridgensis and $E$. parva respectively. The frequency of the species identified in each experiment and the respective groups are shown in Tables 3, 4.

None of the animals (experiment 1 and 2) showed clinical signs attributable to eimeriosis during the experimental period. No suspected adverse local or systemic drug reaction was reported in any treated animal.

Table 1. Comparative results among the means counts of oocysts per gram of feces (OPG) and the efficacy (\%) in lactating lambs at three months of age kept in pasture conditions with creep feeding that were either treated with an experimental formulation containing toltrazuril $7.5 \%+$ Trimix $^{\mathrm{TM}}$ (group A) or left untreated with anticoccidial drugs (group B) on a commercial farm from September 2013 to October 2013 in Mato Grosso do Sul State, Brazil.

\begin{tabular}{cccr}
\hline \multirow{2}{*}{ Date of collection } & \multicolumn{2}{c}{ GROUP A } & \multicolumn{2}{c}{ GROUP B } \\
\cline { 2 - 3 } & Average OPG (standard error) & Efficacy & Average OPG (standard error) \\
\hline D0 & $595 \pm 213.3^{\mathrm{a}}$ & & $590.9 \pm 218.0^{\mathrm{a}}$ \\
D5 & $42.3 \pm 26.4^{\mathrm{b*}}$ & $90.0(82.4-95.1)$ & $350 \pm 107.1^{\mathrm{a}}$ \\
D10 & $3.8 \pm 3.8^{\mathrm{b} *}$ & $99.4(97.1-100)$ & $564.3 \pm 187.2^{\mathrm{a}}$ \\
D20 & $68 \pm 40.6^{\mathrm{b} *}$ & $87.3(78.3-92.9)$ & $800 \pm 242.6^{\mathrm{a}}$ \\
\hline
\end{tabular}

${ }^{1}$ : Treatment day. Different letters in the same column indicate that the means values of the OPG counts differed significantly (p<0.05) by ANOVA. *: Average results of OPG scores between the treated group and the control group were significant $(\mathrm{p}<0.05)$ at a given time, by ANOVA. 
Table 2. Comparative results among the mean counts of oocysts per gram of feces (OPG) and the efficacy in weaned lambs treated with an experimental formulation containing toltrazuril 7.5\% + Trimix $^{\text {TM }}$ (Group I), Taurotec ${ }^{\circledR}$ (Group II) and those left untreated with anticoccidial (Group III) in feedlot conditions from September 2013 to October 2013 in Mato Grosso do Sul State, Brazil.

\begin{tabular}{|c|c|c|c|c|c|}
\hline \multirow{2}{*}{$\begin{array}{l}\text { Date of } \\
\text { collection }\end{array}$} & \multicolumn{2}{|c|}{ GROUP I } & \multicolumn{2}{|c|}{ GROUP II } & \multirow{2}{*}{$\begin{array}{c}\text { GROUP III } \\
\begin{array}{c}\text { Average OPG } \\
\text { (standard error) }\end{array}\end{array}$} \\
\hline & $\begin{array}{c}\text { Average OPG } \\
\text { (standard error) }\end{array}$ & Efficacy & $\begin{array}{c}\text { Average OPG } \\
\text { (standard error) }\end{array}$ & Efficacy & \\
\hline $\mathrm{D}^{1}$ & $2191.6 \pm 793.4^{a}$ & - & $1570.8 \pm 532.8^{a}$ & - & $1395.8 \pm 487.7^{\mathrm{a}}$ \\
\hline D7 & $33.3 \pm 21.6^{\mathrm{b} *}$ & $98.2(96.6-99.2)$ & $416.6 \pm 103.9^{b}$ & $72.7(65.8-78.0)$ & $540.9 \pm 241.3^{\mathrm{ab}}$ \\
\hline D21 & $160 \pm 48.2^{c}$ & $92.6(90.0-95.1)$ & $287.5 \pm 127.8^{\mathrm{bc}}$ & $81.6(76.4-86.1)$ & $320 \pm 112.7^{\mathrm{ab}}$ \\
\hline $\mathrm{D} 42$ & $118.7 \pm 63.1^{\mathrm{bc}}$ & 94.5 (91.9-96.3) & $61.1 \pm 23.0^{c}$ & $95.9(93.5-97.7)$ & $77.7 \pm 20^{\mathrm{b}}$ \\
\hline
\end{tabular}

${ }^{1}$ : Treatment day. Different letters in the same column indicate that the mean values of the OPG counts differed significantly $(\mathrm{p}<0.05)$ by ANOVA. *: Average results of OPG scores between the groups were significant $(\mathrm{p}<0.05)$ at a given time, by ANOVA.

Table 3. Frequency (\%) of identified oocysts of Eimeria spp. in fecal samples in three month old lactating lambs treated with an experimental formulation containing toltrazuril $7.5 \%+$ Trimix $^{\mathrm{TM}}$ and those left untreated (control) on a commercial sheep farm from September 2013 to October 2013 in Mato Grosso do Sul State, Brazil.

\begin{tabular}{|c|c|c|c|c|c|c|c|c|}
\hline \multirow{3}{*}{ Eimeria Species } & \multicolumn{8}{|c|}{ Treatment } \\
\hline & \multicolumn{4}{|c|}{ Toltrazuril $7.5 \%$ + Trimix ${ }^{\mathrm{TM}}$} & \multicolumn{4}{|c|}{ Control } \\
\hline & D0 $^{1}$ & D5 & D10 & D20 & D0 & D5 & D10 & D20 \\
\hline E. ahsata & 16.9 & 0 & 0 & 0 & 23.1 & 0 & 4.1 & 15 \\
\hline E. crandallis / E. weybridgensis ${ }^{2}$ & 8.4 & 0 & 0 & 0 & 15.4 & 15 & 30.5 & 17 \\
\hline E. faurei & 0 & 0 & 0 & 0 & 0 & 2.5 & 0 & 0 \\
\hline E. granulosa & 11.8 & 0 & 0 & 0 & 0 & 38.7 & 0 & 12 \\
\hline E. intricata & 0 & 0 & 0 & 0 & 7,7 & 12.5 & 21.0 & 15 \\
\hline E. ovinoidalis & 10.3 & 0 & 0 & 0 & 53.8 & 26.2 & 38.9 & 20 \\
\hline E. parva & 52.6 & 0 & 0 & 0 & 0 & 5 & 5.5 & 21 \\
\hline
\end{tabular}

${ }^{1}$ : Treatment day. ${ }^{2}$ : The oocysts with characteristics of E. crandallis and E. weybridgensis were grouped because of the difficulty of reliably differentiating between these species O’Callaghan et al. (1987).

Table 4. Frequency (\%) of identification of oocysts of Eimeria spp. in fecal samples in five month old weaned lambs kept in feedlot conditions treated with an experimental formulation containing toltrazuril $7.5 \%+$ Trimix $^{\mathrm{TM}}$, lasalocid (Taurotec ${ }^{\circledR}$ ) and those left untreated $(\mathrm{control})$ from September 2013 to October 2013 in Mato Grosso do Sul State, Brazil.

\begin{tabular}{|c|c|c|c|c|c|c|c|c|c|c|c|c|}
\hline \multirow{3}{*}{ Eimeria Species } & \multicolumn{12}{|c|}{ Treatment } \\
\hline & \multicolumn{4}{|c|}{ Lasalocid } & \multicolumn{4}{|c|}{ Toltrazuril 7.5\% + Trimix ${ }^{\mathrm{TM}}$} & \multicolumn{4}{|c|}{ Control } \\
\hline & $\mathrm{D0}^{1}$ & D7 & D21 & $\mathrm{D} 42$ & $\mathrm{D0}^{1}$ & D7 & D21 & D42 & $\mathrm{D0}^{1}$ & D7 & D21 & $\mathrm{D} 42$ \\
\hline E. ahsata & 0 & 0 & 0 & 8.6 & 3.8 & 0 & 0 & 23.1 & 10.8 & 0 & 0 & 12 \\
\hline E. bakuensis & 8.8 & 0 & 14.5 & 0 & 0 & 0 & 0 & 0 & 0 & 0 & 0 & 0 \\
\hline E. crandallis / E. weybridgensis ${ }^{2}$ & 31.6 & 10.3 & 32.3 & 0 & 63.6 & 0 & 9.5 & 0 & 17.8 & 30 & 0 & 22.7 \\
\hline E. granulosa & 7 & 24.2 & 9.7 & 5.7 & 3.8 & 0 & 0 & 15.3 & 0 & 0 & 7.1 & 10.6 \\
\hline E. intricata & 0 & 27.6 & 0 & 37.1 & 0 & 0 & 0 & 0 & 0 & 35 & 14.3 & 20 \\
\hline E. marsica & 0 & 0 & 0 & 8.6 & 0 & 0 & 0 & 0 & 0 & 0 & 0 & 0 \\
\hline E. ovinoidalis & 35.1 & 37.9 & 41.9 & 17.2 & 25 & 0 & 90.5 & 23.1 & 53.6 & 25 & 78.6 & 13.3 \\
\hline E. parva & 17.5 & 0 & 1.6 & 22.8 & 3.8 & 0 & 0 & 38.5 & 17.8 & 10 & 0 & 21.4 \\
\hline
\end{tabular}

${ }^{1}$ : Treatment day. ${ }^{2}$ : Oocysts with characteristics of E. crandallis and E. weybridgensis were grouped because of the difficulty in reliably differentiating between these species O'Callaghan et al. (1987).

\section{Discussion}

Previous studies have reported the efficacy and benefits of using toltrazuril $5 \%$ in lambs under different conditions (LE SUEUR et al., 2009; MUNDT et al., 2009; SCALA et al., 2014). In this study, toltrazuril $7.5 \%+$ Trimix $^{\text {TM }}$ showed high efficacy and reduced the OPG in three month old lambs in an extensive system (experiment 1) as well as in five month old sheep in an intensive system (experiment 2). Toltrazuril is a coccidicidal chemical compound whose mechanism of action involves interfering with nuclear division and the activity of mitochondria, damaging the wall forming bodies in microgametes and producing vacuolation in the endoplasmic reticulum at all intracellular developmental stages of the parasite (HARDER \& HABERKORN, 1989).

The sheep that received treatment with lasalocid sodium and the control group demonstrated a similar reduction in OPG during the experiment. Foreyt et al. (1979) reported that lasalocid obtained a 99\% efficacy in lambs experimentally infected with 
24.000 oocysts and demonstrated an increased weight gain of $6 \mathrm{~kg}$ more than the control animals. Lasalocid sodium is an ionophoric antibiotic classified by its carrier ions that acts mainly in the early stages and asexual forms of the parasite; it is also used as growth promoter to increase weight gain (CLARKE et al., 2014). However, it is difficult to confirm the efficacy of lasolacid sodium in this experiment because the control group showed a reduced mean OPG. This may be due to appropriate supplementation leading to some degree of immunity, which promoted a reduction in oocyst shedding in the feces (ANDRADE et al., 2012). In addition, an inverse relationship between weight gain and the average number of oocysts excreted has been reported (REEG et al., 2005).

No significant difference in weight gain was found between groups in experiment 2. Scala et al. (2014) demonstrated the benefits of treatment with toltrazuril for weight gain in weaned lambs, but Mundt et al. (2009) and Saratsis et al. (2013) did not find any significant increase in the body weight gains of treated lambs and control animals. The magnitude of the effects is dependent on the severity of the infection and the degree of contamination with pathogenic species (FITZGERALD \& MANSFIELD, 1973). Little is known about the impact of subclinical coccidiosis on the performance of sheep (GAULY et al., 2004).

In this experiment, Eimeria infections were distributed in eight species, the most common being E. ovinoidalis, E. crandallis/E. weybridgensis and E. parva. Saratsis et al. (2011) reported that $E$. parva is not related to acute cases of diarrhea in naturally acquired infections, but had reported that this species decreased the body weight gain of infected animals (BERRIATUA et al., 1994). Eimeria ovinoidalis is considered the most pathogenic, and accounts for the majority of clinical cases of the disease (CATCHPOLE et al., 1976; CHARTIER \& PARAUD, 2012). E. ovinoidalis and E. crandallis have a high multiplicity in relation to the others and are thus frequently observed in sheep (CATCHPOLE et al., 1976) and a high parasitic load of pathogenic species causes a reduction in weight gain (CHARTIER \& PARAUD, 2012).

\section{Conclusions}

Treatment with an experimental formulation of toltrazuril $7.5 \%$ + Trimix $^{\mathrm{TM}}$ reduced the infection by Eimeria spp. in lactating lambs managed for 20 days as well as in sheep under feedlot conditions until the 42 nd day after treatment. There was no significant difference in body weight gain between the different treatments. The most frequent species observed was E. ovinoidalis. Despite this parasite being recognized as pathogenic, there were no animals with clinical signs of eimeriosis during the experimental period.

\section{Acknowledgements}

The authors would like to thank CNPq (National Council for Scientific and Technological Development, Brazil) for Grants to L.E.R. Tavares (311567/2013-4) and F. Paiva (311018/2013-0) and CAPES for the scholarship award to F.S. Rodrigues.

\section{References}

Agyei AD, Odonkor M, Osei-Somuah A. Concurrence of Eimeria and helminth parasitic infections in West African dwarf kids in Ghana. Small Rumin Res 2004; 51(1): 29-35. http://dx.doi.org/10.1016/S09214488(03)00184-6.

Agyei AD. Epidemiological studies on gastrointestinal parasitic infections of lambs in the coastal savanna regions of Ghana. Trop Anim Health Prod 2003; 35(3): 207-217. http://dx.doi.org/10.1023/A:1023339328589.

Andrade ALF Jr, Silva PC, Aguiar EM, Santos FGA. Use of coccidiostat in mineral salt and study on ovine eimeriosis. Rev Bras Parasitol Vet 2012; 21(1): 16-21. http://dx.doi.org/10.1590/S1984-29612012000100004. PMid:22534939.

Ayres M, Ayres M Jr, Ayres DL, Santos AAS. Bioestat: aplicações estatísticas nas áreas das Ciências Biomédicas. Versão 5.0. Belém: Sociedade Civil Mamirauá; 2007.324 p.

Berriatua E, Green LE, Morgan KL. A descriptive epidemiological study of coccidiosis in early lambing housed flocks. Vet Parasitol 1994; 54(4): 337-351. http://dx.doi.org/10.1016/0304-4017(94)90001-9.

Catchpole J, Norton CC, Joyner LP. Experiments with defined multispecific coccidial infections in lambs. Parasitology 1976; 72(2): 137-147. http:// dx.doi.org/10.1017/S0031182000048447. PMid:1264487.

Chartier C, Paraud C. Coccidiosis due to Eimeria in sheep and goats, a review. Small Rumin Res 2012; 103(1): 84-92. http://dx.doi.org/10.1016/j. smallrumres.2011.10.022.

Clarke L, Fodey TL, Crooks SRH, Moloney M, O’Mahony J, Delahaut $\mathrm{P}$, et al. A review of coccidiostats and the analysis of their residues in meat and other food. Meat Sci 2014; 97(3): 358-374. http://dx.doi. org/10.1016/j.meatsci.2014.01.004.

Diaferia M, Veronesi F, Morganti G, Nisoli L, Fioretti DP. Efficacy of toltrazuril 5\% suspension (Baycox ${ }^{\circledR}$, Bayer) and diclazuril (Vecoxan ${ }^{\circledR}$, Janssen-Cilag) in the control of Eimeria spp. in lambs. Parasitol Res 2013; 112(S1): 163-168. http://dx.doi.org/10.1007/s00436-013-3440-1.

Fitzgerald PR, Mansfield ME. Efficacy of monensin against bovine coccidiosis in young Holstein-Friesian calves. J Protozool 1973; 20(1): 121-126. http://dx.doi.org/10.1111/j.1550-7408.1973.tb06014.x. PMid:4690645.

Foreyt WT, Gates NL, Wescott RB. Effects of lasalocid and monensin against experimentally induced coccidiosis in confinement-reared lambs from weaning to market weight. Am J Vet Res 1979; 40(1): 97-100. PMid:453691.

Gauly M, Reeg J, Bauer C, Erhardt G. Influence of production systems in lambs on the Eimeria oocysts output and weight gain. Small Rumin Res 2004; 55(1-3): 159-167. http://dx.doi.org/10.1016/j.smallrumres.2004.02.001.

Gordon HML, Whitlock HV. A new technique for counting nematode eggs in sheep faeces. J Counc Sci Ind Res 1939; 12(1): 50-52.

Harder A, Haberkorn A. Possible mode of action of toltrazuril: studies on two Eimeria species and mammalian and Ascaris suum enzymes. Parasitol Res 1989; 76(1): 8-12. http://dx.doi.org/10.1007/BF00931064. PMid:2560189.

Hoffman WA, Pons JA, Janer JL. The sedimentation concentration method in Schistosomiasis mansoni. J Publ Hlth Trop Med 1934; 9: 281-298.

Kanyari PWN. Experimental infections with coccidiosis and serum antibody quantitation in two breeds of goats. Vet Parasitol 1988; 28(1-2): 11-18. http://dx.doi.org/10.1016/0304-4017(88)90014-3. PMid:3388728. 
Kanyari PWN. The relationship between coccidial and helminth infections in sheep and goats in Kenya. Vet Parasitol 1993; 51(1-2): 137-141. http:// dx.doi.org/10.1016/0304-4017(93)90204-Z. PMid:8128577.

Le Sueur C, Mage C, Mundt HC. Efficacy of toltrazuril (Baycox 5\% suspension) in natural infections with pathogenic Eimeria spp. in housed lambs. Parasitol Res 2009; 104(5): 1157-1162. http://dx.doi.org/10.1007/ s00436-008-1305-9.

Mundt H, Dittmar K, Daugschies A, Grzonka E, Bangoura B. Study of the comparative efficacy of toltrazuril and diclazuril against ovine coccidiosis in housed lambs. Parasitol Res 2009; 105(S1): 141-150. http:// dx.doi.org/10.1007/s00436-009-1505-y.

O'Callaghan MG, O’Donoghue PJ, Moore E. Coccidia in sheep in South Australia. Vet Parasitol 1987; 24(3-4): 175-183. http://dx.doi. org/10.1016/0304-4017(87)90038-0. PMid:3617424.

Reeg KJ, Gauly M, Bauer C, Mertens C, Erhardt G, Zahner H. Coccidial infections in housed lambs: oocyst excretion, antibody levels and genetic influences on the infection. Vet Parasitol 2005; 127(3-4): 209-219. http:// dx.doi.org/10.1016/j.vetpar.2004.10.018. PMid:15710521.
Saratsis A, Joachim A, Alexandros S, Sotiraki S. Lamb coccidiosis dynamics in different dairy production systems. Vet Parasitol 2011; 181(2-4): 131 138. http://dx.doi.org/10.1016/j.vetpar.2011.04.027.

Saratsis A, Karagiannis I, Brozos C, Kiossis E, Tzanidakis N, Joachim A, et al. Lamb eimeriosis: applied treatment protocols in dairy sheep production systems. Vet Parasitol 2013; 196(1-2): 56-63. http://dx.doi. org/10.1016/j.vetpar.2013.01.020.

Scala A, Varcasia A, Dore F, Solinas C, Mula P, Carta A, et al. Evaluation of efficacy of toltrazuril and diclazuril in the control of subclinical eimeriosis in weaned lambs. Small Rumin Res 2014; 120(2-3): 242-246. http://dx.doi.org/10.1016/j.smallrumres.2014.05.015.

Torgerson PR, Paul M, Furrer R. Evaluating faecal egg count reduction using a specifically designed package "eggCounts" in $\mathrm{R}$ and a user friendly web interface. Int J Parasitol 2014; 44(5): 299-303. http://dx.doi. org/10.1016/j.ijpara.2014.01.005.

Ueno H, Gonçalves PC. Manual para diagnóstico das helmintoses de ruminantes. 4nd ed. Tokyo: JICA; 1998. 